\title{
THE INFLUENCE OF PROJECT-BASED LEARNING-STEM MODEL ON STUDENT LEARNING OUTCOMES
}

\author{
Akhmad Darmawan ${ }^{1}$ \\ ${ }^{1}$ SMAN 2 Taruna Bhayangkara Jawa Timur \\ Banyuwangi, 68465, Indonesia \\ adn08031977@gmail.com \\ DOI: https://doi.org/10.21107/jps.v7i2.6443
}

\begin{abstract}
This study aims to determine the effect of the project-based learning-STEM model on biology learning outcomes in growth and development. The learning was carried out in class XII IPA students of SMA Negeri 1 Muncar in the 2018/2019 academic year. This type of research is quasi-experimental research. The instrument in this study was a test given in the experimental class and the control class. The data were analyzed using parametric statistical analysis. There is a difference in the average post-test learning outcomes of the experimental class (PjBL-STEM model) with the control class's post-test learning outcomes using the independent sample t-test. The results of the analysis show that Sig. (2-tailed) of $0.00<0.05$, which can be interpreted that there is a significant difference in the average student learning outcomes between the PJBL-STEM model (experimental class) and the conventional model (control class). The average post-test score of the experimental class with the PjBL-STEM model was 87.50, while the average score in the Control class was 79.82 so that there was an increase in the value of 7.68 in the experimental class. The PjBL-STEM model's application to improve learning outcomes can be continued with other materials that have STEM characteristics.
\end{abstract}

Keywords: PjBL-STEM, Learning Outcomes, Biology

\footnotetext{
${ }^{1}$ Corresponding Author
} 


\section{Introduction}

The US National Science Foundation coined the term STEM in the 90s as a theme for educational reform action in all four disciplines. The activity boosts the workforce in STEM fields, develops STEM-literate citizens, and enhances US global competitiveness in science and technology innovation. This reform of STEM education has been driven by study reports that show a shortage of candidates to fill jobs in STEM fields. Significant levels of literacy within the community on STEM-related issues and where US high school students are in TIMSS and PISA outcomes. Based on TIMSS data, American children continue to lag in math and science compared to their Asian counterparts (Bhandal, 2018). The highest number of Singaporean students in South Korea, Japan, and Hong Kong (Bhandal, 2018).

STEM education has resonated in various countries, both developed and developing countries, which view STEM education as a solution to problems with the quality of human resources and each country's competitiveness. Today, STEM education is being adopted by many countries as a blueprint for educational innovation, thus emerging as a global movement to bridge the gap between the need and availability of skills necessary for economic development in the 21st century. STEM-based learning can train students' abilities and talents to face 21 st-century problems (Jauhariyyah, 2017). Indonesia is experiencing the gap between the need and availability of human resources. Referring to the 2010 Central Bureau of Statistics data, Indonesia's human resources are still dominated by less skilled apes (as many as 88 million). It is predicted that in 2020 there will be a $50 \%$ shortage of workers to fill vacancies in the employment structure. However, solving this problem is not an easy matter because it is impossible to develop basic skills and soft skills (collaboration, communication, creativity, and problem-solving).

The 2013 curriculum addresses the problems of the quality and quantity of Indonesian human resources with global daylight if they systematically prepare them to develop the knowledge, skills, and attitudes required by the 21 st-century world of work, as manifested in STEM Education. Education with a STEM approach can be the key to creating the next generation of nations who can compete in the global arena. Therefore, STEM Education needs to be a frame of reference for Indonesia's educational process in the future.

Project-Based Learning (PjBL) is a learning model that uses a learning process project and is a student center (Kemendikbud, 2017). The PjBL model

\section{Pengaruh Model Project Based Learning STEM}

gives students the freedom to plan their learning activities, carry out tasks collaboratively, and ultimately produce work products presented to others (Kemendikbud, 2017). PjBL is innovative learning that encourages students to carry out investigations, work collaboratively in researching and creating projects that apply their knowledge of discovering new things, are proficient in using technology, and can solve problems (Bell, 2010).

PjBL-STEM can increase student interest in learning, meaningful learning, and help students solve problems and support future careers. PjBL-STEM provides challenges and motivation for students because it can train students to think critically, analyze and improve higher-order thinking skills (Tseng et al. 2013; Afriana et al., 2016). Thus, the integration of PjBL with STEM can optimize learning activities that support student learning outcomes.

All necessary competencies in biology subjects can use the STEM Approach. These necessary competencies need to be analyzed first. The topic of Growth and Development was chosen using the STEM approach because, based on the study results, it contained the scope of knowledge or science related to applied technology that could be engineered by considering mathematical calculations (Maulani, 2018). We researched the effect of cooperative learning in the STEM Project-Based Learning model on learning outcomes of biology, growth, and development of living things for class XII IPA students of SMA Negeri 1 Muncar in the 2018/2019 academic year.

\section{Research Methods}

Quasi-experimental research is applied in this research. Pretest and posttest are given to determine changes in learning outcomes (Munir, 2011). The design used can be seen in table 1 .

Table 1. Research Design

\begin{tabular}{cccc}
\hline Group & Pre-test & Treatment & Post-test \\
\hline E & $\mathrm{P}_{1}$ & $\mathrm{X}_{1}$ & $\mathrm{O}_{1}$ \\
K & $\mathrm{P}_{2}$ & $\mathrm{X}_{2}$ & $\mathrm{O}_{2}$ \\
\hline
\end{tabular}

Information:

$\mathrm{E}=$ Experiment Class

$\mathrm{K}=$ Control Class

$\mathrm{P}_{1}=$ Pre-Test experiment class

$\mathrm{P}_{2}=$ Pre-Test control class

$\mathrm{X}_{1}=$ Treatment with PjBL STEM Model

$\mathrm{X}_{2}=$ Treatment without PjBL STEM Model

$\mathrm{O}_{1}=$ Post-test experiment class

$\mathrm{O}_{2}=$ Post-test control class

We research SMA Negeri 1 Muncar, Banyuwangi. Research time was on 23 July - 10 November 2018 with the topic of the growth and development of living things.

The research subjects were all students of class XII IPA SMA Negeri 1 Muncar. 


\section{Darmawan}

Determination of the control class and the experimental class was carried out by using a random sampling technique. The control class as a group received conventional learning, and the experimental class as a group received treatment in the form of PjBL-STEM learning. The independent variable in this study is the PjBL-STEM cooperative learning model. This study's dependent variable is the biology learning outcomes of class XII IPA students of SMA Negeri 1 Muncar. One of the data collection techniques in this study is to use tests. Tests were carried out before and after learning was carried out, namely pre-test and posttest. The pre-test aims to measure how much knowledge students have before the teaching and learning process, while the post-test is to assess how much changes in learning outcomes achieved by students after the learning process.

The steps of this research are: 1) preparation, namely studying the STEM unit of the growth and development material of the P4TK IPA which is used as a reference in implementing the PjBL-STEM model of learning; 2) determine the population by using purposive sampling area technique; 3) determine the research sample, namely the experimental class and the control class using the lottery technique; 4) giving a pre-test to the experimental class and the control class before learning activities to determine students' learning abilities and motivation before learning activities take place; 5) carry out the teaching and learning process with different treatments, namely the experimental class using the PjBL-STEM model while the control class uses the conventional method, namely the lecture and discussion methods commonly used by teachers; 6) provide post-test in the experimental class and control class after learning activities to determine student learning outcomes after learning activities take place; 7) conducting interviews with several students as research supporting data; 8) analyzed data using the independent sample $t$ test using SPSS for windows version 22.0 .; 9) discussing the results of data analysis supported by interview data; and 10) draw conclusions from the results of the research that has been done.

\section{Result and Discussion}

Low student learning outcomes need to be resolved immediately by finding an appropriate learning model. One of the learning models that can be used to overcome this problem is the $\mathrm{PjB}$ STEM model. The PjBL-STEM model affects scientific literacy, creativity, and student learning outcomes (Lutfi, 2018). STEM education provides opportunities for teachers to show students how concepts, principles, and techniques from science, technology, engineering, and mathematics are used in an integrated manner to develop products, processes, and systems used in their daily lives. STEM education is an interdisciplinary approach to learning. Students use science, technology, engineering, and mathematics in a real context that connects schools, the world of work, and the global world, thus developing STEM literacy, enabling students to compete in the new economic era knowledge-based. STEM-based learning is one alternative learning that can be used to build 21 stcentury skills (Permanasari, 2016).

STEM education prepares the 21 st-century workforce. With STEM education and related activities, students can apply what they learn in the classroom/laboratory to their future work in the real world. This can increase student motivation so that it can improve learning outcomes. The problem-solving strategy for the low learning outcomes of students at SMAN 1 Muncar is by applying the PjBL-STEM model.

The normality test of the pre-test and posttest values of the experimental class and control class using the Kolmogorov-Smirnov test can be seen in table 2. Based on the calculation of the distribution of the pre-test and post-test values of the experimental class (PjBL-STEM model) and the control class in table 2. It is known that the significance for the pre-test experimental class is 0.200 , the pots test for the experimental class is 0.156 , the pre-test for the control class is 0.200 , and the post-test for the control class is 0.093 . Because the probability (p) of all values is known to be $p>0.05$, it can be concluded that the values are normally distributed. After knowing that the data is normally distributed, it can be continued using the parametric test (paired sample test and independent-sample test) to analyze the research data.

The homogeneity test is used to determine whether the variance of the post-test data of the experimental class with the PjBL-STEM model and the post-test data of the control class is homogeneous or not. Based on the data calculation results (table 3), the significance value (sig.) Based on the mean is $0.908>0.05$, so it can be concluded that the variance of the post-test data for the experimental class and the control class is the same or homogeneous. Thus, one of the requirements of an independent $t$-test is fulfilled.

The paired sample t-test was carried out using SPSS version 22.0. Based on table 4, it is obtained that the sig (2-tailed) value is 0.000 
$<0.05$. It can be concluded that there is a difference in the average student learning outcomes for the pre-test experimental class and the post-test experiment. Based on the output pair 2, the sig (2tailed) value is $0.000<0.05$, it can be concluded that there is a difference in the average student learning outcomes for the control class pretest and the control posttest (conventional model). Based on the discussion of output pair 1, it can be concluded that there is an effect of the PjBLSTEM model on student learning outcomes in

\section{Pengaruh Model Project Based Learning STEM}

biology subjects, material growth, and development of living things.

Based on the independent sample t-test, the Sig value was obtained. (2-tailed) of $0.00<0.05$, it can be concluded that there is a difference in the average student learning outcomes between the PjBL STEM learning model (experimental class) and the conventional model (control class). The difference in learning outcomes in the post-test average of the experimental class and the control class can be seen in table 5 .

Table 2. Normality Test

\begin{tabular}{|c|c|c|c|c|c|c|}
\hline & \multirow[b]{2}{*}{ Kelas } & \multicolumn{3}{|c|}{ Kolmogorov-Smirnov $^{\mathrm{a}}$} & \multicolumn{2}{|c|}{ Shapiro-Wilk } \\
\hline & & Statistic & Df & Sig. & Statistic & $\mathrm{df}$ \\
\hline Learning & Pre Test - Experiment & .114 & 28 & $.200^{*}$ & .972 & 28 \\
\hline \multirow[t]{3}{*}{ Outcomes } & Pos Test - Experiment & .142 & 28 & .156 & .946 & 28 \\
\hline & Pre Test - Control & .114 & 28 & $.200^{*}$ & .972 & 28 \\
\hline & Pos Test - Control & .153 & 28 & .093 & .959 & 28 \\
\hline
\end{tabular}

Table 3. Homogeneity Test

\begin{tabular}{|c|c|c|c|c|c|c|}
\hline & & & Levene Statistic & df1 & df2 & Sig. \\
\hline Students & Learning & Based on Mean & .014 & 1 & 54 & .908 \\
\hline \multirow[t]{3}{*}{ Outcomes } & & Based on Median & .026 & 1 & 54 & .873 \\
\hline & & $\begin{array}{l}\text { Based on Median and with } \\
\text { adjusted df }\end{array}$ & .026 & 1 & 51.456 & .873 \\
\hline & & Based on trimmed mean & .012 & 1 & 54 & .912 \\
\hline
\end{tabular}

Table 3. Paired T-Test

\begin{tabular}{|c|c|c|c|c|c|c|c|c|c|}
\hline & & \multicolumn{5}{|c|}{ Paired Differences } & \multirow[b]{3}{*}{$\mathrm{T}$} & \multirow[b]{3}{*}{ df } & \multirow{3}{*}{$\begin{array}{l}\text { Sig. } \\
\text { (2-tailed) }\end{array}$} \\
\hline & & \multirow[b]{2}{*}{ Mean } & \multirow{2}{*}{$\begin{array}{l}\text { Std. } \\
\text { Deviation }\end{array}$} & \multirow{2}{*}{$\begin{array}{l}\text { Std. } \\
\text { Mean }\end{array}$} & \multicolumn{2}{|c|}{$\begin{array}{l}\text { 95\% Confidence Interval } \\
\text { of the Difference }\end{array}$} & & & \\
\hline & & & & & Lower & Upper & & & \\
\hline Pair 1 & $\begin{array}{l}\text { Pre Test - Post Test } \\
\text { Experiment }\end{array}$ & -47.679 & 6.733 & 1.272 & -50.289 & -45.068 & -37.469 & 27 & .000 \\
\hline Pair 2 & $\begin{array}{l}\text { Pre Test - Post Test } \\
\text { Control }\end{array}$ & -39.643 & 5.079 & .960 & -41.612 & -37.674 & -41.304 & 27 & .000 \\
\hline
\end{tabular}

Tabel 6. Statistic Descriptive

\begin{tabular}{llllll}
\hline & N & Minimum & Maximum & Mean & Std. Deviation \\
\hline Pre Test Experiment & 28 & 20 & 60 & 39.82 & 10.227 \\
Post Test Experiment & 28 & 75 & 100 & 87.50 & 6.872 \\
Pre Test Control & 28 & 20 & 60 & 40.18 & 10.227 \\
Post Test Control & 28 & 65 & 95 & 79.82 & 7.263 \\
Valid N (listwise) & 28 & & & & \\
\hline
\end{tabular}

Based on the data in table 5 , it can be seen that the average post-test in the experimental class with the PjBL-STEM model is 87.50, while the average in the Control class is 79.82 . There was an 


\section{Darmawan}

increase in the average post-test score of 7.68 using PjBL-STEM on the growth and development of living things. This is also in line with Muharohmah (2017) research, which concluded that there is a significant difference between the learning outcomes of the experimental class and the control class. The experimental class has better learning outcomes than the control class. ProjectBased Learning (PjBL) model based on STEM (Science, Technology, Engineering, and Mathematics) can improve students 'mastery of concepts and can improve students' critical thinking skills (Afifah et al., 2019). The PjBL STEM model can improve students' mastery of high-category Ecosystem material (Astuti et al., 2019). This is because the activities carried out in learning are more oriented towards active student involvement, stimulating students to think critically.

Increased mastery of concepts, activities, and critical thinking skills can improve student learning outcomes. STEM literacy development is not an easy matter. It takes at least a decade to develop STEM education in a country (Firman, 2015). The first two years are required to initiate STEM education reform to design, develop, and implement unit STEM learning models. The next six years to include STEM education into the curriculum. The next two years are needed to continue STEM reform, namely building schools' capacity to carry out continuous improvement of STEM education programs. This resulted in not many STEM learning units being formed. The existing STEM learning units are still very limited. To overcome this, you can use the STEM learning unit, the growth and development material that has been made by Maulani (2018) from P4TK IPA as a reference. This can facilitate and accelerate teacher preparation in implementing the PjBL-STEM learning model.

Previous research on STEM conducted by Syukri (2013) proved that STEM in education shows that teaching and learning science using STEM-minimal as a whole shows positive results for students. In addition to increasing achievement and interest in science, students also show a positive attitude towards the world of entrepreneurship. Another research on STEM conducted by Khaeroningtyas (2016) shows that STEM-based learning can improve students' scientific literacy.

Rahim (2015) argues that the STEM learning model involves various learning fields that emphasize real-life learning and students' experiences using science, technology, engineering, and mathematics. The PjBL-STEM learning model affects student learning outcomes because, during the learning process, it provides direct experience to students in the classroom. Students gain experience by making products that are developed in their minds. Students make products that are developed based on the results of group discussions and existing knowledge of themselves.

The PjBL-STEM learning model affects student learning outcomes because the teaching and learning process using the STEM model provides meaningful science learning. Students develop a product based on their ideas through group discussions. This will give students a meaningful impression because they can develop a product so that the material being studied is easy to understand and remember.

Furthermore, the PjBL-STEM learning model affects student learning outcomes because it provides students opportunities to make discoveries during the science learning process. Students create products by developing existing products by discovering new ideas from group discussions, according to scientific theories, formulas, and concepts and containing STEM principles, namely science, technology, engineering, and mathematics. Bruner's Learning Theory in Suardi (2015: 149) suggests that the learning process will run well and creatively if the teacher provides opportunities for students to find a concept, theory, rule, or understanding through examples found in everyday life. This is in line with the opinion of Wardiningrum (2015), who states that science is a way of finding out about nature systematically so that it is not only the mastery of a collection of knowledge in the form of facts, concepts, or principles but also a process of discovery.

Students are not accustomed to using the PjBL-STEM model, resulting in a longer time required than the teacher's learning scenario. This is because students who are not used to learning using the PjBL STEM model are still adapting to this new model. In addition, the experience of students who do not directly visit the place of business so that there are difficulties in making designs and assembling models from the designs that have been made. The material on animal growth and development can be overcome by directing students to make field observations to hydroponic business actors. Teachers must also be good at directing, guiding, and motivating students in planning models and making products.

Students who take PjBL-STEM education have high-level thinking skills, are innovative, 
independent, tech-savvy, invent, solve problems, and make decisions (Sariah, 2016). STEM education has several advantages, namely creating a meaningful and enjoyable learning experience, increasing interest, and motivation to learn in STEM education. The implementation of STEM in education integrates knowledge, skills, and values in the subject in depth through an inquiry approach, project-based learning, and problembased learning in a real-world context.

\section{Conclusion}

The PjBL-STEM model on growth and development material has a significant effect on student learning outcomes. The average post-test score of the experimental class with the PjBL STEM model was 87.50 , while the average score in the Control class was 79.82, so that there was an increase in the value of 7.68 in the experimental class. It is necessary to conduct other research on the PjBL STEM learning model's effect on learning motivation and learning outcomes. The application of the PjBL STEM model to improve learning outcomes can be continued with other science materials that have STEM characteristics.

\section{References}

Afifah, A. N., Ilmiyati, N., \& Toto (2019). Model Project Based Learning (PjBL) Berbasis STEM Untuk Meningkatkan Penguasaan Konsep Dan Keterampilan Berpikir Kritis Siswa. Quagga: Jurnal Pendidikan dan Biologi, 11 (2) 73-78

Afriana, J. et al. (2016). Penerapan Project Based Learning Terintegrasi STEM untuk Meningkatkan Literasi Sains Siswa Ditinjau dari Gender. Jurnal Inovasi Pendidikan IPA, $2(2)$.

Astuti, I. D., Toto \& Yulisma, L. (2019). Model Project Based Learning (PjBL) Terintegrasi STEM Untuk Meningkatkan Penguasaan Konsep dan Aktivitas Belajar Siswa. Quagga: Jurnal Pendidikan dan Biologi , 11 (2) $93-97$

Bell, S. (2010). Project-based Learning for the 21st century: Skills for the future. The Clearing House, 83(2), 39-43.

Bhandal, A. (2018). STEM The Future of Amerika How to Improve Science, Technology,
Engineering, and Match Education in American System? New York: NY

Firman, H. (2015). Pendidikan Sains Berbasis STEM: Konsep, Pengembangan dan Peranan Riset Pasca sarjana. Seminar Nasional Pendidikan IPA dan PKLH Program Pascasarjana Universitas Pakuan.

Jauhariyyah, R. F. et al. (2017). Science, Technology, Engineering and Mathematics Project Based Learning (STEM-PjBL) pada Pembelajaran Sains. Pros. Seminar Pend. IPA Pascasarjana UM. Vol. 2.

Kemendikbud. (2017). Buku Guru Ilmu Pengetahuan Alam. Jakarta: PT.Tiga Serangkai Pustaka Mandiri.

Khaeroningtyas. (2016). STEM Learning In Material of Temperature and Its Change to Improve Scientific Literacy of Junior High School Students. Jurnal Pendidikan IPA Indonesia. Volume. 2, No. 94-100

Lutfi, et al. (2018). Pengaruh Project Based Learning Terintegrasi Stem Terhadap Literasi Sains, Kreativitas dan Hasil Belajar Peserta Didik. Prosiding Seminar Nasional Biologi dan Pembelajarannya. http://ojs.unm.ac.id/semnasbio/index. (diunduh tgl 8 Nopember 2018)

Maulani, H. A. (2018). Unit Pembelajaran STEM Biologi SMA Pertumbuhan dan Perkembangan pada Tanaman. Bandung: P4TK IPA

Muharohmah, D. R. (2017). Pengaruh Pembelajaran STEM (Science, Technology, Engineering and Mathematics) Terhadap Hasil Belajar Peserta didik pada konsep Evolusi. Skripsi tidak diterbitkan. Jakarta: Universitas Islam Negeri Syarif Hidayatullah Jakarta.

Munir, A. S. (2011). Pengaruh Model Pembelajaran Problem Solving Dengan Media Animasi Terhadap Motivasi dan Hasil Belajar Siswa di SMA Negeri 2 Tanggul. Skripsi tidak diterbitkan. Jember: Program Studi Pendidikan Biologi FKIP UNEJ.

Permanasari, A. (2016). STEM Education: Inovasi dalam Pembelajaran Sains. Prosiding Seminar Nasional Pendidikan 


\section{Darmawan}

Sains

https://www.neliti.com/id/conferences/snps-

vi-2016 (diunduh $\operatorname{tgl} 8$ Nopember 2018).

Rahim, F. (2015). Pemerkasaan Ulul Albab melalui modul STEM bersepadu STEMind. Journal of Islamic Education. Volume 2, No. $1-12$

Sariah. (2016). Panduan pelaksanaan Sains, Teknologi, Kejuruteraan, dan Matematik (STEM) dalam Pengajaran dan pembelajaran. Kementrian Pendidikan Malaysia: Malaysia.

Suardi. (2015). Belajar \& Pembelajaran. Yogyakarta: Deepublish

Syukri, M. (2013). Pendidikan STEM dalam Entrepreneurial Science Thinking "ESciT": Satu Perkongsian Pengalaman dari UKM untuk Aceh. Aceh Development Internasional Conference. Volume 1. No. 105-112.

Wardiningrum, M. 2015. Penerapan Pembelajaran Cooperative Learning Model STAD Berbantukan Media Video Pembelajaran untuk Meningkatkan Aktivitas dan Hasil Belajar IPA. Jurnal Pena Sains.Volume. 2, No. 1 . 